\title{
An overview of current and potential hill country livestock systems
}

\author{
S.T. MORRIS and R.E. HICKSON \\ Institute of Veterinary, Animal and Biomedical Sciences, Massey University, \\ Private Bag 11222, Palmerston North 4410, New Zealand
}

s.t.morris@massey.ac.nz

\begin{abstract}
This paper reviews current production trends for sheep and beef cattle production in New Zealand and gives some insight into the opportunities for improvement. The New Zealand climate favours pasture growth and this is the key to sheep and beef cattle production with over $95 \%$ of the diet being grazed pasture or crop. Exports are the focus of the industry with $92 \%$ of sheep meat and $82 \%$ of beef exported. There has been a $72 \%$ increase in sheep meat production since 1990, but there still remains opportunity for further increases through breeding sheep at an earlier age, increasing the weight of lambs weaned per ewe per year, increased efficiency of breeding cows and utilisation of calves from the dairy industry for beef production.
\end{abstract}

Keywords: Sheep meat, beef cattle, pasture, intensification, environment

\section{Key messages}

- There has been considerable increase in sheep and beef production over last 25 years despite a decrease numbers

- There are opportunities to improve production via increased weight of lamb weaned per ewe and breeding ewe lambs successfully

- Cattle systems need to improve the efficiency of breeding cows and exploit the opportunities for beef production from cattle of dairy industry origin.

\section{Introduction}

Sheep and beef cattle production are the dominant land uses in New Zealand, utilising $66 \%$ or 9.7 million hectares of the agricultural land (Ministry of Primary Industries 2012). Today they are predominately located in hill country and in the land classes classified by the Beef + Lamb New Zealand Economic Service as South Island hill country, Class 2, North Island hard hill country, Class 3, and North Island hill country, Class 4. Together they comprise an estimated $49 \%$ of all farms (Beef + Lamb New Zealand 2015a), and thus form the basis of the visual and social landscape of New Zealand. The sheep and beef sectors have a strong export focus with around $82 \%$ of beef, $92 \%$ of sheep meat, and $90 \%$ of wool exported (Morris 2013). New Zealand is the largest exporter of lamb meat accounting for approximately $47 \%$ of the world's trade in lamb
(Morris 2009). Pastures are permanent especially those in less cultivatable hill country although there has been a tendency in recent years to increase the percentage of sown pasture with mixed results (Tozer et al. 2013; 2014). Of the total area farmed with sheep and beef cattle, the annual rate of pasture renewal has been reported to be just $2.3 \%$ compared with $8 \%$ on dairy cattle farms which are generally on flatter more fertile land (Stewart et al. 2014). Many hill country farms have mixed livestock systems that include sheep, beef cattle, deer, and dairy heifers and/or wintered dairy cows. With the downturn in dairy prices there may be less opportunity for dairy heifer or wintering dairy cows in the short to medium term.

This paper reviews some aspects of sheep and beef production over last 20-30 years detailing gains made in production levels, and outlines areas where further gains may be possible in hill country sheep and beef cattle production systems.

\section{Changing practices on New Zealand sheep and beef cattle farms}

Examples of change in practices on New Zealand sheep and beef farms include implementation of pregnancy scanning, body condition scoring, improved lamb survival, and the feeding of triplet-bearing ewes pre-lambing to enhance survival. Changes also include, use of terminal sires and crossbreeding and composites in sheep and beef cow herds, selection for improved growth rate in sheep and beef cattle, improved reproductive performance of sheep flocks, breeding at younger ages, introduction of whole-herd/ flock health plans, once-bred heifers and bull beef production (Morris \& Kenyon 2014). Changes have occurred also in the genetic makeup of the flocks and herds through importation of new breeds (sheep and cattle) to meet industry demand (improved growth and meat production in cattle and sheep and improved reproduction in sheep). Many composite breeds have been developed and stabilised.

These changes have resulted in an impressive increase in per animal production despite a dramatic decline in livestock numbers (Table 1). Mackay et al. (2011) noted there has been little change in stocking rates in the last 20 years but a dramatic lift in livestock performance with sheep meat production increasing by $72 \%$ on hard hill country farms since $1989 / 1990$. 
There has been a 23\% increase in lambing percentage from $98 \%$ in 1987 to $121 \%$ in 2013 , and average carcass weights for lambs have increased from 14 to 18 $\mathrm{kg}$. It is estimated that this increase in carcass weight equated to a $50 \mathrm{~g} /$ day improvement in lamb growth rate without changes in stocking rate and little change in the slaughter pattern (Bray 2004).

Lambing percentages range from 125\% (lambs tailed/100 ewes mated) on South Island class 2 hill country to $131 \%$ on North Island class 4 hill country (Table 2). The potential under more-intense management on improved land could be vastly greater as many farmers are already achieving lambing percentages greater than $150 \%$ (Thomson et al. 2004). Cattle systems remained similar with the cow-calf

Table 1 Total livestock numbers (000) in New Zealand in 1985, 1995, 2005 and 2015. (Source: Beef \& Lamb New Zealand Economic Service, various reports).

\begin{tabular}{lcccc}
\hline & 1985 & 1995 & 2005 & $\mathbf{2 0 1 5}$ \\
\hline Sheep & 67854 & 48816 & 44002 & 28570 \\
Dairy cattle & 3308 & 4090 & 4494 & 6750 \\
Beef cattle & 4613 & 5183 & 4787 & 3590 \\
Deer & 320 & 1179 & 1800 & 950 \\
Goats & 427 & 256 & 175 & 160 \\
\hline
\end{tabular}

systems dominating on hard hill country although some farmers have changed to all finishing dairy beef bred bulls or steers and others have sought to improve the value of their cattle products via Wagyu or branded beef such as Angus Pure. Wool contributes 10-15\% of the gross income from sheep (Table 2), decreasing as the class of land improves, whereas cattle contribute 25- $40 \%$ of total revenue with improving class of land. Earnings before interest, tax and rent also increases with improving class of land (Table 2).

\section{What is the potential in the future?}

Research indicates considerably higher levels of production are possible. Farmlet experiments at Massey University indicate that over $720 \mathrm{~kg}$ lamb carcass weight/ ha/year is possible on plantain and red and white clover mixed pastures, compared with $400 \mathrm{~kg} / \mathrm{ha} /$ year on the traditional ryegrass/white clover mixed pasture (Kemp et al. 2010). While these results were achieved on flat land there is opportunity to use this on cultivatable land on some hill country properties. Earlier research indicated $1000 \mathrm{~kg}$ beef carcass weight/ha is possible with Friesian bulls (Cosgrove et al. 2003). However, McRae (2003) suggested 500-600 kg beef carcass weight/ha is the likely average performance level. Two potential areas of hill country sheep performance that could be increased are now outlined.

Table 2 Average statistics for three types of hill country sheep/cattle farms of New Zealand (2014-2015). (Adapted from Beef + Lamb New Zealand 2015a).

\begin{tabular}{|c|c|c|c|}
\hline & $\begin{array}{c}\text { Class } 2 \\
\text { South Island Hill Country }{ }^{1}\end{array}$ & $\begin{array}{c}\text { Class } 3 \\
\text { North Island Hard Hill Country }\end{array}$ & $\begin{array}{c}\text { Class } 4 \\
\text { North Island Hill Country }\end{array}$ \\
\hline Area/farm ha & 1496 & 798 & 429 \\
\hline Stock units & 6639 & 6310 & 4051 \\
\hline SU/ha² & 4.4 & 7.9 & 9.3 \\
\hline Calving \% & 84.1 & 81.5 & 85.9 \\
\hline Lambing \% & 124.9 & 121.0 & 130.9 \\
\hline Fawning \% & 82.1 & 75.0 & 76.9 \\
\hline \multicolumn{4}{|l|}{$\%$ Gross Revenue } \\
\hline Wool sales & 15.4 & 12.9 & 10.3 \\
\hline Sheep sales & 48.8 & 48.2 & 44.6 \\
\hline Cattle sales & 26.5 & 35.6 & 39.7 \\
\hline Deer & 1.7 & 0.7 & 0.7 \\
\hline Other ${ }^{3}$ & 7.6 & 2.6 & 3.6 \\
\hline Gross Revenue \$/ha & 398 & 666 & 956 \\
\hline $\mathrm{FWE}^{4}$ as a $\% \mathrm{GR}$ & 59.2 & 50.6 & 48.7 \\
\hline EBITR $^{5} \$ /$ ha & 118 & 252 & 395 \\
\hline
\end{tabular}

\footnotetext{
${ }^{1}$ Farm classification system used by Beef + Lamb New Zealand Economic Service (http://www.beeflambnz.com/information/on-farm-data-and-industry-production/sheep-beef-farm-survey/nsi/)

2 SU = livestock stock units (for New Zealand one Stock Unit equates to one $55 \mathrm{~kg}$ ewe rearing a lamb and consuming $550 \mathrm{~kg}$ DM/year)

${ }^{3}$ Other includes goat and cash crop revenue

${ }^{4}$ Farm working expenses

${ }^{5}$ Earnings before interest, tax and rent.
} 


\section{Increasing weight of lamb weaned per mature ewe bred per year}

There are two opportunities for New Zealand hill country sheep farmers. Firstly, to increase the survival of multiple-born lambs and secondly to improve their growth rates and hence the total weight of lamb weaned per ewe bred. A direct result of the increase in the lambing percentage in the New Zealand flock is that many farmers now have more than $10 \%$ and $50 \%$ triplet- and twin-bearing ewes, respectively, within their flock. The flow-on effect of increased ewe fecundity is greater lamb mortality rates especially in the lightestborn lambs within twin- and triplet-born litters (Morel et al. 2008).

Data suggests that the average weaning liveweights of twin- and triplet-born lambs are 28 and $25 \mathrm{~kg}$, respectively (Morris \& Kenyon 2014), while lamb mortality rates are in the range of 15 to $20 \%$ and 25 to $35 \%$ on average, respectively (Thomson et al. 2004; West et al. 2009). These are lower than the $32 \mathrm{~kg}$ weaning liveweight and 10 to $15 \%$ mortality in singletons (West et al. 2009). Identification of optimal feeding conditions in pregnancy and in lactation and their interaction with ewe body condition could enable lamb liveweights and survival rates to be increased by at least 5 to $10 \%$. Compared with twin-born lambs, triplet-born lambs have been shown to have lighter birth weights (Morris \& Kenyon, 2004), lower rectal temperatures, lower plasma fructose, T3 and T4 concentrations and greater plasma lactate concentrations within 5 minutes of birth (Stafford et al. 2007). These physiological characteristics can result in poor lamb survival during the post-natal period. Thermoregulatory studies to date indicate summit metabolic rates (an indicator of heat production) do not differ between twin- and tripletborn lambs on a per kg body weight basis (Kerslake et al. 2010). There have been initiatives to improve triplet lamb survival under hill country conditions using a triplet transfer system where one of a triplet is mothered onto a ewe with a single-born lamb (Beef + Lamb New Zealand 2015b). Triplet-bearing ewes have also been lambed indoors in an attempt to improve survival to $280 \%$ while another approach is to rear one of a set of triplet-born lambs artificially and wean at $9 \mathrm{~kg}$ and then feed a concentrate-based feed plus pasture (Beef + Lamb New Zealand 2015c).

Ewes of greater body condition are more likely to be able to cope with a lower level of nutrition than their counterparts with poor condition. In the future, it is recommended that farmers have specific nutritional management plans for ewes in pregnancy and in lactation based on their body condition score. This approach would allow for targeted feeding to maximise the likely outcome for the flock (Kenyon et al. 2014a). It should also be recognised that any response to nutrition in either late pregnancy or in lactation is highly dependent on what the ewe is was fed or offered in the other period.

When ewes fail to meet their nutritional requirements in late pregnancy they must rely on their body reserves to buffer against this shortfall. For multiple-bearing and rearing ewes the optimum pre- and post-grazing herbage masses for a ryegrass white clover sward are 1100 and $800 \mathrm{~kg} \mathrm{DM} /$ ha to day 136 of pregnancy, and then not below $1200 \mathrm{~kg} \mathrm{DM} / \mathrm{ha}$ for late pregnancy and lactation (Kenyon et al. 2011a,b; Kenyon et al. 2012; Kenyon et al. 2013).

In twin- and triplet-bearing ewes little benefit has been reported from improved nutritional regimens in early pregnancy if the ewes are subsequently adequately fed in late pregnancy (Kenyon et al. 2011b). These results suggest multiple-bearing ewe intakes in early pregnancy can be controlled to save herbage for later in pregnancy, with minimal, if any, impact on animal performance.

In theory, the nutrient intake of ewes can be increased by offering concentrate supplements that are less bulky than pasture. Research showed that offering concentrate sheep pellets in addition to ryegrass/white clover pasture was not an efficient means of improving ewe and lamb performance and was not cost effective (Kerslake et al. 2009), and was logistically challenging under New Zealand hill country conditions. Improving nutrition with alternative forages such as a herb sward mix of plantain, red and white clover in late pregnancy and in lactation increased ewe milk production and lamb survival and growth (Hutton et al. 2011). Also, in triplet-bearing/rearing ewes produced more total lamb liveweight per ewe at weaning than the traditional ryegrass/white clover herbage. Similar improvements in lamb growth have been observed in lucernebased dryland farms (Stevens et al. 2012) and with subterranean clover in Marlborough hill country (Grigg et. al. 2008). An economic analysis should always be undertaken to ensure the benefits to establishing alternative forages on areas of flat land or cultivatable hill country, outweigh the costs. These results indicate that herb/clover mixes and the use of other forages such as annual clovers and summer rape crops to supply high quality feed in feed deficit periods, have the potential to transform sheep production systems in New Zealand, especially in highly fecund flocks. There is the potential that these specialist high quality forages could be used to wean lambs onto early while still achieving similar ages at slaughter, especially under dry conditions when ryegrass quality can be poor. They could also be used as a means for allowing singletonborn lambs to be slaughtered at an even earlier age and thus improving the efficiency of a singleton lamb system. The establishment of herb pastures and clovers 
on uncultivatable hill country has been the focus of substantial extension and farm trials in recent times with some success in some seasons (Daniell \& Buckley 2015).

Managing ewes on body condition score has also been a focus with the research suggesting twin-bearing ewes of body condition score 2.0 or greater can be offered restricted feeding levels (down to pasture covers of $800 \mathrm{~kg} \mathrm{DM} / \mathrm{ha}$ ) to at least day 136 of pregnancy with few implications for their lambs. This assumes they are well fed in lactation (offered an herbage mass of not less than $1200 \mathrm{~kg} \mathrm{DM} / \mathrm{ha}$ ). If the latter scenario does not hold then a condition score of 3.0 would be more desirable. With triplet bearing ewes, the minimum body condition score should be 2.5 in the last month of pregnancy (Everett-Hincks et al. 2013; Kenyon et al. 2014a).

\section{Breeding ewe lambs successfully}

Advantages from breeding ewe lambs include: improved utilisation of additional herbage in spring through extra demand, an increase in total number of lambs born per farm per year, a selection tool for ewe replacements, increased selection pressure for replacements as more lambs are born, a reduction in greenhouse gas emissions per unit of product produced and increased lifetime reproductive performance (Kenyon et al. 2014b). Only 25 to $30 \%$ of ewe lambs are bred on New Zealand farms with the remainder bred for the first time at 17 to 19 months of age. While the lambing percentage of ewe lambs is often only half of that achieved by the mature ewe flock, considerable variation exists indicating ewe lambs are capable of achieving weaning percentages greater than $100 \%$ on a flock basis (Kenyon et al. 2014b). An additional issue with ewe lamb breeding is that the weight of lambs weaned and lamb survival can be lower in lambs born to ewe lambs compared with mature ewes (Corner et al. 2013; Kenyon et al. 2014b). To achieve high performance levels with ewe lamb breeding, an integrated management approach is needed and involves appropriate management from when the ewe lamb herself is weaned until she is re-bred at 18 to 19 months of age (Kenyon et al. 2014b). If ewe lambs are not managed appropriately their performance will be disappointing in that year and it will be poor the following year and its lifetime performance can be negatively affected. However, if well managed, lifetime performance can be increased (Kenyon et al. 2014b).

One of the biggest drivers of success with ewe lamb breeding is liveweight (or body condition) at breeding (Kenyon et al. 2014b). Ewe lambs should be a minimum of $60-70 \%$ of their mature liveweight at breeding. The guidelines are that ewe lambs need to be a minimum of $40 \mathrm{~kg}$ at breeding (mature weight of $65 \mathrm{~kg}$ ) and gaining approximately $130 \mathrm{~g} / \mathrm{d}$ in total live weight throughout pregnancy. Body condition score is also an excellent tool to determine if a ewe lamb should be bred. Romney-type ewe lambs should have a body condition score in the range of 2.5 to 3.5 at breeding (Cave et al. 2012). Achieving these liveweight targets are challenging in hill country and certainly necessitates a planned management programme to gain successful outcomes. If farmers are trying to finish lambs for slaughter as well as grow ewe lambs to appropriate breeding weights, then under hard hill country conditions, something has to give in the system i.e. reduced stocking rate or all sale lambs gone by late January or early February.

\section{High performance beef systems}

Beef breeding cow numbers have been declining for many years, on average by $2.1 \%$ per year over the past 10 years (Beef + Lamb New Zealand 2015d). Total numbers of steers, heifers and bulls processed have remained relatively static over the same period (Beef + Lamb New Zealand 2015e), necessitating an increase in the proportion of finishing cattle sourced from dairy herds.

The pressures on the beef cow to remain economically competitive with other stock classes mean that efficiency of production has become increasingly important. The performance of the beef cow remains compromised by her role in controlling surplus feed in summer/autumn within hill country farming systems, whereby her feed intake is driven not by feed requirements for maximum performance, but by the quantity and quality of pasture available after the needs of other stock classes are met. Nevertheless, many farmers achieve high performance from their beef cows whilst still enjoying the flexibility and pasture-control advantages offered by those cows.

Efficiency of production (calf output relative to feed intake by the beef herd) is driven by the weight of the calf weaned relative to the weight of the cow, and by the reproductive rate of the cow. Genetic selection for increased growth rate and carcass weight of steers has often resulted in concurrent increases in cow liveweight. The use of crossbreeding systems in which a smaller maternal breed of cow is mated with a terminal sire that offers rapid growth and superior carcass traits offers a $10 \%$ increase in weigt of calf weaned/cow liveweight at weaning compared with a traditional straight-bred beef system (Law et al. 2013). This increased efficiency results partly from the ability to fit different breeds or types to different roles in the system, and partly from heterosis. A highly efficient breeding cow is one that converts a greater proportion of her feed intake into calf weaning weight via milk, rather than into her own body reserves. The use of Angus-cross-dairy cows in such a system has been demonstrated to consistently offer an increase in calf weaning weight of around $10 \%$ 
of maternal body weight compared with straight-bred Angus cows (Law et al. 2013; Hickson et al. 2014a, 2014b), reflective of the increased milk yield and lower body condition score of the dairy-cross cows. These cows also offer an advantage in that there is a readily available supply of first-cross females for replacements from the dairy industry.

The reproductive rate of beef breeding cows remains a major factor limiting their potential production. Weaning percentage has remained static at around $85 \%$ for many years whilst weaning percentage of ewes has increased dramatically during the same period. Research in a Massey University herd indicated that for every cow that does not conceive a calf, there is another cow that was diagnosed pregnant and carried through the winter only to not wean a calf (Hickson et al. 2015). Thus, in addition to focussing on conception rate, future work should also focus on factors contributing to foetal loss and neonatal calf deaths.

Studies investigating twinning in beef cows have identified both benefits and limitations to the system (Cummins et al. 2008; Smeaton \& Clayton 1998), but it is unlikely that twinning is going to be a widespread objective for beef cattle farmers at present. Instead, calving heifers at 2 years of age offers a means of increasing herd reproductive rate and provided appropriate bulls are used for breeding with maiden heifers to manage the risk of dystocia, this is likely to increase profitability of the beef herd (Hickson et al. 2010).

As with breeding ewe lambs, breeding heifers requires reasonable liveweight gain before mating and during pregnancy, and will increase the priority of the young replacement stock in the farm system.

Nevertheless, even with increases in calf output from calving 2-year-old heifers, it is clear that the beef breeding cow herd will not be able to supply enough finishing cattle, and increased use will be made of the calf resource produced by the dairy industry. Currently, Friesian bull calves are reared for bull beef, and beefcross-dairy calves, predominantly males, are reared for either bull beef or prime steer finishing. These calves are largely reared artificially, and low-cost, earlyweaning systems of calf rearing have been devised to produce $100 \mathrm{~kg}$ weaners at 12 weeks of age (Muir et al. 2000a). An efficient beef finishing system requires an average growth rate of near $1 \mathrm{~kg} /$ day from birth to slaughter, but growth rates for weaned calves on lowquality summer pasture are often around 300-400 g/ day and remain a weak point of dairy-beef finishing systems. Similar to work with finishing lambs, recent experiments have reported superior growth rates for weaned bull calves grazed on a chicory/plantain/red and white clover mixed pasture than for calves grazed on ryegrass/white clover. Growth rate of weaned bulls on the herb mix was also superior to the growth rate of calves supplemented with $2 \mathrm{~kg}$ of commercial calf meal per day, and this mix shows huge potential to add value in a dairy-beef system.

Challenges in the dairy-beef arena remain, around the identification and selection of appropriate bulls that both perform for the dairy farmer in terms of calving ease and gestation length, but also add value to the finisher by achieving high growth rates and superior carcass quality. The New Zealand dairy herd is becoming increasingly dominated by Kiwi-cross cows, so the incorporation of part-Jersey cattle into the beef herd remains a challenge. The meat quality of such cattle is remarkably similar to that from traditional beef breeds (Muir et al. 2000b; Schreurs et al. 2014) but they are slower growing and finish at lighter weights (Vazquez et al. 2013; Collier et al. 2015). In addition, a proportion of Jersey-crossbred cattle may be downgraded because of excessively yellow fat. The selection of appropriate calves for rearing from the dairy industry is a critical step for the success of the dairy-beef industry.

\section{Conclusions}

Productivity gains over the last 20 years in the sheep and beef industry have been impressive but there remains ample opportunity to realise further gains. There are opportunities to improve production via increased weight of lamb weaned per ewe and breeding ewe lambs successfully. Cattle systems need to improve the efficiency of breeding cows and exploit the opportunities for beef production from cattle of dairyindustry origin. To achieve these gains then research, development and extension must focus on hill country, especially if it is to remain sustainable in the longer term.

\section{REFERENCES}

Beef + Lamb New Zealand. 2015a. Beef + Lamb New Zealand sheep \& beef farm survey. Accessed 12/11/15. http://www.beeflambnz.com/information/ on-farm-data-and-industry-production/sheep-beeffarm-survey/.

Beef + Lamb New Zealand. 2015b. Wairarapa demonstration farm. Accessed 20/11/15. http:// www.beeflambnz.com/Documents/Farm/Triplet $\% 20$ transfer\%20system\%20presentation.pdf.

Beef + Lamb New Zealand. 2015c. Focussing on lamb survival. Accessed 20/11/15. http://www.beeflambnz. com/news-events/News/2014/june/focusing-onlamb-survival/.

Beef + Lamb New Zealand. 2015d. Beef + Lamb New Zealand stock number survey. Accessed.24/11/15. http://www.beeflambnz.com/Documents/ Information/Stock\%20number\%20survey.pdf. 
Beef + Lamb New Zealand. 2015e. Export cattle slaughter. Accessed 24/11/15. http://www. beeflambnz.com/Documents/Information/cattle $\% 20$ slaughter\%20trend.pdf.

Bray, A. 2004. More lambs from less. Primary Industry Management 7: 32-33.

Cave, L.M.; Kenyon, P.R.; Morris, S.T. 2012. Effect of timing of exposure to vasectomised rams and ewe lamb body condition score on the breeding performance of ewe lambs. Animal Production Science 52: 471-477.

Collier, K.J.D.; Hickson, R.E.; Schreurs, N.M.; Martin, N.P.; Kenyon, P.R.; Morris, S.T. 2015. Growth rate and carcass characteristics of Simmental- and Angussired steers born to Angus and Angus-cross-dairy cows. Proceedings of the New Zealand Society of Animal Production 75: 15-19.

Corner, R.A.; Mulvaney, F.J.; Morris, S.T.; West, D.M.; Morel, P.C.H.; Kenyon, P.R. 2013. A comparison of the reproductive performance of ewe lambs and mature ewes. Small Ruminant Research 114: 126133.

Cosgrove, G.P.; Clark, D.A.; Lambert, M.G. 2003. High production dairy-beef cattle grazing systems: a review of research in the Manawatu. Proceedings of the New Zealand Grassland Association 65: 21-28.

Cummins, L.J.; Morris, C.A.; Kirkpatrick, B.W. 2008. Developing twinning cattle for commercial production. Australian Journal of Experimental Agriculture 48: 930-934.

Daniell, D.; Buckley, S. 2015. How to optimise pasture production off uncultivatable hill country. Proceedings of the New Zealand Grassland Association 77: 57-60.

Everett-Hincks, J.M.; Stevens, D.; Rendel, J.M.; Smith, T. 2013. The effect of pre-lamb condition score on triplet performance in a commercial flock. Proceedings of the New Zealand Society of Animal Production 73: 126-130.

Grigg, D.W.; Grigg, J.M.; Lucas, R.J. 2008. Maximising subterranean clover in Marlborough's hill country is key to weaning $80 \%$ of sale lambs prime. Proceedings of the New Zealand Grassland Association 70: 25-29.

Hickson, R.E.; Lopez-Villalobos, N.; Kenyon, P.R.; Ridler, B.J.; Morris, S.T. 2010. Profitability of calving heifers at 2 compared with 3 years of age and the effect of incidence of assistance at parturition on profitability. Animal Production Science 50: 354358.

Hickson, R.E.; Corner-Thomas, R.A.; Kenyon, P.R.; Morris, S.T.; Martin, N.P.; Lopez-Villalobos, N. 2015. Survival of beef-cross-dairy crossbred breeding cows. Proceedings of the New Zealand Society of Animal Production 75: 159-163.
Hickson, R.E.; Back, P.J.; Martin, N.P.; Kenyon, P.R.; Lopez-Villalobos, N.; Morris S.T. 2014a. Differences in live weight and milking potential does not affect reproductive efficiency in beef breeding cows. p. 537. In: Reproduction in domestic ruminants VIII, Proceedings of the ninth international symposium on reproduction in domestic ruminants, Ohibiro, Hokkaido, Japan. Eds. Juengel, J.L.; Miyamoto, A.; Price, C.; Reynolds, L.P.; Smith, M.F.; Webb, R. Context, Leicestershire, England.

Hickson, R.E.; Lopez-Villalobos, N.; Kenyon, P.R.; Morris, S.T. 2014b. Breed effects and heterosis for productivity traits at first calving of Angus, Holstein Friesian, Jersey and crossbred beef cows. Animal Production Science 54: 1381-1387.

Hutton, P.G.; Kenyon, P.R.; Bedi, M.K.; Kemp, P.D.; Stafford, K.J.; West, D.M.; Morris, S.T. 2011. A herb and legume mix increased ewe milk production and ewe and lamb live weight gain to weaning compared to a ryegrass dominant sward. Animal Feed Science and Technology 164: 1-7.

Kemp, P.D.; Kenyon, P.R.: Morris, S.T. 2010. The use of legume and herb forage species to create high performance pastures for sheep and cattle grazing systems. Revista Brasileira Zootecnia 39: 169-174.

Kenyon, P.R.; Morris, S.T.; Stafford, K.J.; West, D.M. 2011a. The effect of ewe body condition and nutrition in late pregnancy on the performance of tripletbearing ewes and their progeny. Animal Production Science 51: 557-564.

Kenyon, P.R.; Morris, S.T.; Stafford, K.J.; West, D.M. 2011b. Does early pregnancy nutrition affect the performance of triplet bearing ewes and their progeny to weaning? New Zealand Journal of Agricultural Research 54: 115-123.

Kenyon, P.R.; Morris, S.T.; Hickson, R.E.; Stafford, K.J.; West, D.M. 2012. Nutritional restriction of triplet-bearing ewes and body condition score has minimal impacts. New Zealand Journal of Agricultural Research 55: 359-370.

Kenyon, P.R.; Morris, S.T.; Hickson, R.E.; Back, P.J.; Ridler, A.L.; Stafford, K.J.; West, D.M. 2013. The effects of body condition score and nutrition of triplet-bearing ewes in late pregnancy. Small Ruminant Research 113: 154-161.

Kenyon, P.R.; Maloney, S.K.; Blache, D. 2014a. Review of sheep body condition in relation to production characteristics. New Zealand Journal of Agricultural Research 57: 38-64.

Kenyon, P.R.; Thompson, A.N.; Morris, S.T. $2014 b$. Breeding ewe lambs successfully to improve lifetime performance. Small Ruminant Research 118: 2-15.

Kerslake, J.L.; Kenyon, P.R.; Stafford, K.J.; Morris, S.T.; Morel, P.C.H. 2009. The effect of offering concentrate supplement to twin- and triple-bearing 
ewes grazing a $60 \mathrm{~mm}$ herbage sward height on lamb birth weight, heat production and post-natal growth. Journal of Agricultural Science (Cambridge) 147: 613-624.

Kerslake, J.L.; Kenyon, P.R.; Morris, S.T.; Stafford, K.J.; Morel, P.C.H. 2010. Physical and physiological factors associated with twin- and triplet-born lamb heat production at 24 to 36 hours of age. Proceedings of the New Zealand Society of Animal Production 70: 286-290.

Law, N.L.; Hickson, R.E.; Lopez-Villalobos, N.; Kenyon, P.R.; Morris, S.T. 2013. Efficiency of beef breeding cows that vary in live weight and milking potential. Proceedings of the New Zealand Society of Animal Production 73: 11-16.

Mackay, A.; Rhodes, A.P.; Power, I.; Wedderburn, M.E. 2011. Has the eco-efficiency of sheep and beef farms changed in the last 20 years. Proceedings of the New Zealand Grassland Association 73: 119-124.

Ministry for Primary Industries. 2012. Pastoral input trend in New Zealand: A snapshot. ISBN 978-0-47838864-0. Accessed 25/11/15 http://www.mpi.govt. nz/document-vault/4168

McRae, A.F. 2003. Historical and practical aspects of profitability in commercial beef production systems. Proceedings of the New Zealand Grassland Association 65: 29-34.

Morel, P.C.H.; Morris, S.T.; Kenyon, P.R. 2008. Effects of birthweight on survival in triplet born lambs. Australian Journal of Experimental Agriculture 48: 984-987.

Morris, S.T. 2009. Economics of sheep production. Small Ruminant Research 86: 59-62.

Morris, S.T. 2013. Sheep and beef cattle production systems. pp. 79-84. In: Ecosystem services in New Zealand - conditions and trends. Ed. Dymond, J.R. Manaki Whenua Press, Lincoln, New Zealand.

Morris, S.T.; Kenyon, P.R. 2004. The effect of litter size and sward height on ewe and lamb performance. New Zealand Journal of Agricultural Research 47: 275286.

Morris, S.T.; Kenyon, P.R. 2014. Intensive sheep and beef production from pasture - A New Zealand perspective of concerns, opportunities and challenges. Meat Science 98: 330-335.

Muir, P.D.; Nieuwenhuis, G.; Smith, N.B.; Ormond, A.A. 2000a. A comparison of rearing systems for dairy beef calves. Proceedings of the New Zealand Grasslands Association 62: 9-11.

Muir, P.D.; Wallace, G.J.; Dobbie, P.M.; Bown, M.D. 2000b. A comparison of animal performance and carcass and meat quality characteristics in
Hereford, Hereford x Friesian, and Friesian steers grazed together at pasture. New Zealand Journal of Agricultural Research 43: 193- 205.

Schreurs, N.M.; Hickson, R.E.; Coleman, L.W.; Kenyon, P.R.; Martin, N.P.; Morris, S.T. 2014. Quality of meat from steers born to beef-cross-dairy cows and sired by Hereford bulls. Proceedings of the New Zealand Society of Animal Production 74: 229232.

Smeaton, D.C.; Clayton, J.B. 1998. Productivity and profitability of twinning beef cows. Proceedings of the New Zealand Society of Animal Production 58: 245-247.

Stafford, K.J.; Kenyon, P.R.; Morris, S.T.; West, D.M. 2007. The physical state and metabolic status of lambs of different birth rank soon after birth. Livestock Science 111: 10-15.

Stevens, D. R.; Thompson, B.R.; Carruthers, A.; Wall, A. J.; Casey, M.J.; Phiskie R.; Young, P.; Moot, D.J. 2013. Understanding the role of spring grazing of Lucerne in the Central Otago environment. Proceedings of the New Zealand Grassland Association 74: 69-76.

Stewart, A.; Kerr, G.; Lissaman, W.; Rowarth, J. 2014. Pasture and forage plants for New Zealand. (4 ${ }^{\text {th }}$ ed.). Grassland Research and Practice Series. New Zealand Grassland Association, Dunedin, New Zealand.

Thomson, B.C.; Muir, P.D.; Smith, N.B. 2004. Litter size, lamb survival, birth and twelve week weight in lambs born to cross-bred ewes. Proceedings of the New Zealand Grassland Association 66: 233-237.

Tozer, K.N.; Douglas, G.B.; Cameron, C.A.; Fraser, T.J.; Moss, R.A.; Rennie, G.M.; Knight, L.; Muir, P.D. 2013. Pasture establishment on non-cultivable hill country. Proceedings of the New Zealand Grassland Association 75: 215-220.

Tozer, K.N.; Douglas, G.B.; Moss, R.A.; Rennie, G.M.; Knight, L.; Fraser, T.J.; Cameron, C.A.; Muir, P.D. 2014. Early performance of oversown pasture mixtures on non-cultivable hill country at four geoclimaically different sites. Proceedings of the New Zealand Grassland Association 76: 155-162.

Vazquez, C.G.; Hickson, R.E.; Morris, S.T.; LopezVillalobos, N.; Kenyon, P.R.; Garcia-Muniz, J.G. 2013. Post-weaning growth in beef and dairy crossbred steers. Proceedings of the Association for the Advancement of Animal Breeding and Genetics 20: 467-470.

West, D.M.; Bruere, A.N.; Ridler, A.L. 2009. The sheep: health, disease $\&$ production, p. $85,3^{\text {rd }}$ ed. Vet Learn Foundation, Wellington, New Zealand. 
